\title{
OUTWARD FDI, MERCHANDISE AND SERVICES TRADE: EVIDENCE FROM SINGAPORE
}

\author{
Koi Nyen Wong ${ }^{1}$, Soo Khoon Goh ${ }^{2}$ \\ ${ }^{1}$ Business School, Sunway University, No. 5 Jalan Universiti, Bandar Sunway, \\ 46150 Petaling Jaya, Selangor Darul Ehsan, Malaysia \\ ${ }^{2}$ Centre for Policy Research and International Studies, \\ Universiti Sains Malaysia, 11800 Penang, Malaysia \\ E-mails: ${ }^{1}$ koinyenw@sunway.edu.my; ${ }^{2}$ skgoh@usm.my (corresponding author)
}

Received 27 September 2011; accepted 14 June 2012

\begin{abstract}
This paper aims to explore the causality pattern between outward foreign direct investment (OFDI) and major external trade components (i.e. exports and imports of merchandise as well as services) using Singapore as a case study, since it is one of the largest outward investors in the Asian region and it is overtly trade-dependent. The findings reveal that there is evidence of an OFDI-led trade hypothesis, particularly with regard to merchandise exports and imports, which is an indication OFDI opens important channels for intra-firm trade activities, home country sourcing and backward integration. However, there is no evidence of causality relationships between Singapore's OFDI and services trade because the purpose of such services is mainly to provide a market presence in the consuming country. As such, Singaporean multinationals are likely to outsource their services either from the host country services sector or from their own services-supporting subsidiaries that have been relocated abroad. The present study provides implications for policy formulation to strengthen OFDI-services trade linkages.
\end{abstract}

Keywords: outward FDI, multinationals, Singapore, Granger causality, merchandise and services trade.

Reference to this paper should be made as follows: Wong, K. N.; Goh, S. K. 2013. Outward FDI, merchandise and services trade: evidence from Singapore, Journal of Business Economics and Management 14(2): 276-291.

JEL Classification: F21.

\section{Introduction}

As globalization continues to increase, the world economy is becoming more integrated and interdependent, leading to a rapid expansion of international trade as well as foreign direct investments (FDIs). One of the salient features of the globalization process is a change in the FDI pattern, that is, a rise in outward FDI (OFDI) activities by developing economies of the Southeast and East Asian regions; this rise is an indication that these regions have become an emerging source of the world's FDI (UNCTAD 2008). As a consequence, this indication has raised an interesting empirical question pertaining 
to the effects of OFDI on home country trade. However, the literature surveyed shows that relatively little empirical work has been conducted to ascertain the causal linkages between OFDI and the components of external trade. The direction of causality between OFDI and external trade may vary not only between the external trade variables (i.e. exports and imports) but also between the types of trade (i.e. merchandise and services). The aim of this paper is to fill this gap in the empirical literature by examining the causality pattern between OFDI and the external trade components, namely, merchandise imports and exports, as well as services, using Singapore as a case study. Singapore was selected as the site for the case study because the city-state is one of the largest outward investors in the Asian region and is overly dependent on trade (as popularized by her successful engagement in entrepôt trade) ${ }^{1}$. Thus, the main contribution of this study is to provide an additional perspective to the existing literature using external trade component data. Because an empirical analysis based on aggregated external trade data may tend to conceal the economic interactions between OFDI and the trade component variables, the empirical findings may be misleading for policy analysis. Conversely, an empirical analysis using external trade component data may suggest useful implications for policy formulation, such as forging linkages between cross-border direct investments by foreign-controlled and locally controlled firms from Singapore, external trade variables and the type of trade in which Singapore engages.

The structure of this paper is organized as follows. The next section presents a profile of Singapore's OFDI and external trade with a focus on recent developments and economic performance. A sound understanding of the dynamics of the city-state's OFDI and external trade can provide important information on the linkages between the two. Section 3 presents the theoretical considerations, provides a description of the data, and unit root tests, a prerequisite for Granger causality analyses. The causality results are reported and analyzed in Section 4. Finally, concluding remarks and policy implications are discussed in Section 5.

\section{Singapore's OFDI and external trade}

Singapore is renowned as a globalized city-state ${ }^{2}$ in which foreign multinational corporations (MNCs) have played a pivotal role in industrializing the economy and facilitating the country's external trade (which is dominated by merchandise exports and imports). The combined share of merchandise exports and imports in total trade in 2010 was $76.3 \%$ (see Table 1). Since 2007, merchandise exports continued to exceed merchandise imports, resulting in a surplus in merchandise balance (see Table 1). The services account also displays a similar trend in the services balance. Nonetheless, merchandise exports remained an important component of Singapore's external trade

\footnotetext{
${ }^{1}$ The present paper differs from Wong et al.'s (2009) paper, which examined the services trade of inward FDI in Singapore and Malaysia. Their main findings for Singapore showed evidence of bidirectional causality between inward FDI and total trade volume in services. We thank the referee for highlighting this point.

2 Accessed at http://www.ey.com/SG/en/Newsroom/News-releases/News-release---Singapore-takesthird-spot-on-Globalization-Index-2010 (date accessed: June 1, 2011).
} 
vis-à-vis services exports (see Table 2). For instance, in 2010, merchandise exports were the largest foreign exchange earner, contributing approximately $76.1 \%$ to the total export revenue, followed by services exports $(23.9 \%)$.

The city-state's spectacular economic performance and development in the course of the implementation of its open foreign investment policy and liberalized trade regime is well-documented in the literature (e.g., Chia 1986; Pang 1987; Rodan 1989; Regnier 1991; Huff 1995; Murray, Pereira 1995; Islam, Chowdhury 1997; Blomqvist 2001). Despite Singapore's excellent infrastructure (such as ports, air transport, telecommunications, and information technology), rising labor costs and limited natural resources and land, coupled with a small domestic market size ${ }^{3}$ and shrinking export markets, could act as impediments to doing business in the city-state for both domestic firms and Singapore-based foreign affiliates. In response to the previously mentioned domestic constraints, as well as greater competition in costs associated with globalization, the Singaporean government initiated the regionalization drive ${ }^{4}$ to encourage domestic firms to go regional to take advantage of lower labor and land costs (Islam, Chowdhury 1997; Ellingsen et al. 2006). Not only can the strategic relocation of lower-end production activities in low-cost countries ${ }^{5}$ potentially sustain Singapore's international competitiveness while retaining higher-end production activities in the home country, it can also be instrumental in transforming the economy into a human capital- and technologyintensive country (see Lecraw 1985; Aggarwal, Agmon 1990; Ellingsen et al. 2006).

Table 1. Singapore's external trade components (\% share of total trade), 2007-2010

\begin{tabular}{lllll}
\hline External Trade Component & 2007 & 2008 & 2009 & 2010 \\
\hline Merchandise Exports & 42.2 & 40.6 & 39.6 & 40.8 \\
\hline Merchandise Imports & 35.6 & 37.3 & 35.4 & 35.5 \\
\hline Services Exports & 11.8 & 11.8 & 13.6 & 12.8 \\
\hline Services Imports & 10.4 & 10.4 & 11.5 & 11.0 \\
\hline
\end{tabular}

Source: Authors' calculations based on data from Singapore Department of Statistics.

Table 2. Singapore's export components (\% share of total exports), 2007-2010

\begin{tabular}{lcccc}
\hline Export Trade & 2007 & 2008 & 2009 & 2010 \\
\hline Merchandise Exports & 78.1 & 77.5 & 74.5 & 76.1 \\
\hline Services Exports & 21.9 & 22.5 & 25.5 & 23.9 \\
\hline
\end{tabular}

Source: Authors' calculations based on data from Singapore Department of Statistics.

\footnotetext{
${ }^{3}$ For example, Estonia also initiated cross-border direct investment because of its small local market (see Ginevičius, Tvaronavičiene 2005).

${ }^{4}$ Similarly, under the premiership of Dr Mahathir, the Malaysian government encouraged domestic firms to invest abroad to exploit the regional growing market opportunities and expand their market reach (Goh, Wong 2011).

${ }^{5}$ In the literature, Helpman (1984) labeled the increase in FDI that results from accessing low-cost production in low-cost countries "vertical FDI".
} 
According to the UNCTAD (2009) report, Singapore was the fourth largest outward investor among developing countries after China, Hong Kong and India in 2008. OFDI ${ }^{6}$ from Singapore grew from S\$13,622 million in 1990 to $\$ \$ 359,348$ million in 2009, an increase of $2,538 \%$ over the 20 -year period ${ }^{7}$. The considerable increase in OFDI by Singapore was mainly due to the adoption of regionalization strategies and the generous incentives ${ }^{8}$ offered to cross-border direct investors by the Singaporean government, who also took the leading role in establishing regional industrial parks ${ }^{9}$ and ventured abroad through its investment arm, Temasek and other state-owned enterprises (UNCTAD 2005). Table 3 reports Singapore's OFDI by activity. By and large, financial and insurance services and manufacturing activities dominated the city-state's total OFDI between 2006 and 2009. For instance, out of the total OFDI stock in 2009, financial and insurance services had the largest share with 49.5 percent. This share was, however, slightly below its 54.4 percent share in 2006. In the manufacturing activities, OFDI accounted for a greater than 20 percent share of Singapore's total OFDI stock between 2006 and 2009.

Table 4 shows Singapore's OFDI by region from 2006 to 2009. Overall, Asia was Singapore's major OFDI destination, accounting for a greater than 50 percent share of OFDI in 2008 and 2009, while Europe, Australia, New Zealand, and the U.S. became much less important destinations for Singapore's outward investors. Table 5 indicates that within the Asian region, China, Malaysia, Indonesia, Hong Kong and Thailand continued to be the major host countries for Singapore's OFDI. Excluding Hong Kong, these major Asian destinations of Singapore' OFDI were found to be low-cost countries, suggesting that Singaporean firms relocate their labor-intensive activities to these locations with the intention of taking advantage of the low-cost production to maintain their competitive positions and extend their market reach.

In terms of Singapore's OFDI by ownership, there was a relatively high level of participation by Singapore-based foreign-controlled firms, which accounted for a 46 percent share in 1999 , despite their decline to $35 \%$ in $2003^{10}$ (see Table 6). As such, OFDI can be viewed as part of the MNC network in which intra-firm trade is becoming increasingly important to Singapore's export and import trade (i.e. between the parent companies at home and their subsidiaries abroad). Additionally, setting up subsidiaries abroad to take advantage of the lower costs of production could potentially enhance the

\footnotetext{
${ }^{6}$ OFDI refers to an investment in which a direct investor resident in the reporting economy owns 10 percent or more of the ordinary shares or voting power in a non-resident direct investment enterprise. An investment by a resident enterprise with less than 10 percent of the shares will be considered an outward portfolio investment (Singapore Department of Statistics 2008: 9).

${ }^{7}$ Authors' calculation based on data obtained from Singapore's Investment Abroad (various issues).

${ }^{8}$ For example, tax incentives and financial support (see Okposin 1999).

${ }^{9}$ For instance, the Singaporean government established industrial parks in China, India, Vietnam and Indonesia (see Islam, Chowdhury 1997; Yeung 1999).

${ }^{10}$ Singapore's Department of Statistics defines foreign-controlled companies as either wholly owned $(100 \%)$ or majority-owned (at least $50 \%$ of paid-up shares). However, the publication of the ownership structure of Singapore's OFDI has been discontinued since 2004.
} 
Table 3. Singapore's OFDI by activity (\% share), 2006-2009

\begin{tabular}{lcccc}
\hline \multicolumn{1}{c}{ Activity } & 2006 & 2007 & 2008 & 2009 \\
\hline Financial \& Insurance Services & 54.38 & 56.23 & 49.21 & 49.51 \\
\hline Manufacturing & 22.20 & 21.77 & 24.34 & 23.39 \\
\hline Real Estate Activities & 4.07 & 3.83 & 5.48 & 5.62 \\
\hline Wholesale \& Retail Trade & 5.33 & 4.69 & 5.47 & 5.46 \\
\hline Administrative and Support Services & 1.99 & 2.53 & 3.81 & 5.08 \\
\hline Information \& Communication & 5.28 & 4.89 & 4.64 & 4.74 \\
\hline Transport \& Storage & 3.37 & 3.18 & 3.48 & 2.66 \\
\hline Professional, Scientific \& Technical & 2.10 & 1.83 & 2.21 & 2.06 \\
\hline Accommodation, Food \& Beverages & 0.94 & 0.83 & 0.80 & 0.75 \\
\hline Construction & 0.34 & 0.21 & 0.56 & 0.73 \\
\hline Source: Auth
\end{tabular}

Source: Authors' calculations based on data from Singapore's Investment Abroad (various issues).

Table 4. Singapore's OFDI by region (\% share), 2006-2009

\begin{tabular}{lcccc}
\hline \multicolumn{1}{c}{ Region } & 2006 & 2007 & 2008 & 2009 \\
\hline Asia & 48.91 & 46.68 & 54.54 & 52.81 \\
\hline Europe & 13.71 & 14.63 & 14.35 & 16.48 \\
\hline Australia \& New Zealand & 4.92 & 5.85 & 5.98 & 5.43 \\
\hline U.S. & 3.47 & 4.38 & 3.70 & 3.35 \\
\hline Other countries & 7.17 & 10.74 & 4.80 & 5.43 \\
\hline
\end{tabular}

Source: Authors' calculations based on data from Singapore's Investment Abroad (various issues).

Table 5. Singapore's OFDI within Asia (\% share), 2006-2009

\begin{tabular}{|c|c|c|c|c|}
\hline Asia & 2006 & 2007 & 2008 & 2009 \\
\hline China & 27.78 & 28.17 & 31.16 & 30.62 \\
\hline Malaysia & 15.69 & 15.39 & 14.47 & 15.12 \\
\hline Indonesia & 13.87 & 13.6 & 12.92 & 13.84 \\
\hline Hong Kong & 12.91 & 13.46 & 11.59 & 11.35 \\
\hline Thailand & 10.84 & 11.43 & 11.10 & 10.25 \\
\hline Japan & 2.09 & 1.66 & 2.82 & 2.62 \\
\hline Taiwan & 4.33 & 3.46 & 3.43 & 3.03 \\
\hline Philippines & 2.77 & 2.76 & 2.48 & 2.30 \\
\hline
\end{tabular}

Source: Authors' calculations based on data from Singapore's Investment Abroad (various issues).

Table 6. Ownership structure of Singapore's OFDI, 1999-2003

\begin{tabular}{cccccc}
\hline Ownership & 1999 & 2000 & 2001 & 2002 & 2003 \\
\hline Foreign-controlled firms & 46.06 & 41.58 & 41.86 & 36.92 & 35.36 \\
\hline Locally controlled firms & 53.94 & 58.42 & 58.14 & 63.08 & 64.64 \\
\hline
\end{tabular}

Note: Singapore's OFDI by ownership data are only made available by Singapore's Investment Abroad until 2003.

Source: Authors' calculations based on data from Singapore's Investment Abroad (various issues). 
cost competitiveness of the parent companies at home, which in turn could increase the home exports to the rest of the world, on the one hand, and increase home imports from the rest of the world in the case of backward vertical integration ${ }^{11}$.

As Singapore is one of the largest outward investors in the region and trade is needed because Singapore is small, this paper aims to explore the inter-linkages between OFDI from Singapore and its major external trade components (i.e. merchandise exports and imports as well as services) using the Granger causality approach, as extant empirical studies are limited.

\section{Theoretical considerations, data and methodology}

\section{Theoretical Considerations}

The empirical study of the relationship between OFDI and trade is well-documented in the literature. In general, the basis for the empirical work on OFDI-trade relationships is determining whether these two macroeconomic variables are complementary or substitutionary. Broadly speaking, the empirical evidence is mixed. For instance, Horst (1972) found that OFDI is often viewed as a replacement for home exports for U.S. manufacturing firms when they are producing for Canadian markets. Similarly, empirical evidence supporting the proposition that OFDI is substitute for trade can also be found in Svensson (1996), Bayoumi and Lipworth (1997) and Ma et al. (2000). In contrast, empirical findings by Lipsey and Weiss (1984), Helpman (1984), Grossman and Helpman (1989), Brainard (1993, 1997), Lin (1995), Pfaffermayr (1996), Clausing (2000) and Head and Ries (2001) highlighted the complementary relationship between OFDI and trade because foreign affiliates used home inputs to produce outputs in the host countries.

Moreover, as noted by Lim and Moon (2001), OFDI would have a positive effect on home country exports if the foreign subsidiaries were located in relatively new, lessdeveloped countries or in a declining home industry. Furthermore, Goldberg and Klein (1999) and Blonigen (2001) showed mixed evidence in that OFDI had both substitution and complementary effects on trade. Thus, the OFDI-trade relationship was not clearly defined, and many studies have indicated that the outcome of the relationship depends on whether OFDI is horizontal or vertical (e.g., Markusen 1984; Markusen, Venables 1995; Helpman 1984; Helpman, Krugman 1985; Kokko 2006). According to Amiti et al. (2000), the substitutionary relationship tends to take place if horizontal OFDI occurs between countries that are similar in terms of relative endowments and size and when trade costs are moderate to high. On the other hand, vertical OFDI is likely to dominate when countries differ in terms of relative skill endowment and size and trade costs are low.

Another interesting empirical question pertaining to the OFDI-trade relationship is the pattern of causality between OFDI and trade (i.e. exports and imports) ${ }^{12}$. According to

\footnotetext{
${ }^{11}$ Backward vertical integration refers to intermediate inputs that are produced by subsidiaries abroad and are then imported for value-added into the home country.

12 The causal relationship between inward FDI and trade flows has been examined by Kosekahyaoglu (2006).
} 
Fontagné (1999), the causality between OFDI and exports as well as imports could run in the following directions: (a) OFDI may result in home exports due to foreign production by the host country's multinationals with the aim of enhancing the international competitiveness of export trade; (b) home exports may drive OFDI when exports serve as the first stage in an internalization process; (c) OFDI may lead to imports because of backward vertical integration; and (d) imports may drive OFDI due to the relocation of domestic industries abroad caused by declining competitiveness.

\section{Data}

All of the time-series data are annual data, and the estimation period is from 1972 to 2009. Higher-frequency data or data spanning a longer time period would be desirable, but the frequency and sample period are based on the availability of OFDI data, which are retrieved from UNCTAD ${ }^{13}$. The data for trade variables, such as exports and imports of merchandise and services, are obtained from the Department of Statistics, Singapore. All of the raw data are converted into real terms using the GDP deflator before they are transformed into natural logarithms (ln).

\section{Methodology}

The possible causal linkages between Singapore's OFDI and her external trade components can be determined using the Granger causality test (Granger 1969, 1988). The notion of the test is to distinguish whether the causality pattern between the macroeconomic variables of interest is unidirectional, bi-directional or independent. For instance, a variable $\mathrm{X}$ is said to Granger cause $\mathrm{Y}$ if information in the past and present $\mathrm{X}$ improves the forecasts of variable $\mathrm{Y}$. A bi-directional pattern exists if $\mathrm{Y}$ also causes $\mathrm{X}$; otherwise, the causality relationship is only unidirectional. If neither X nor Y causes the other, then the two variables are statistically independent. A tri-variate VAR (vector autoregressive) model for causality analysis is written as follows:

OFDI and Merchandise Trade

$$
\left[\begin{array}{l}
\ln O F D I_{t} \\
\ln E X M_{t} \\
\ln I M M_{t}
\end{array}\right]=\left[\begin{array}{l}
a_{1} \\
a_{2} \\
a_{3}
\end{array}\right]+\left[\begin{array}{l}
\theta_{11}(L) \theta_{12}(L) \theta_{13}(L) \\
\theta_{21}(L) \theta_{22}(L) \theta_{23}(L) \\
\theta_{31}(L) \theta_{32}(L) \theta_{33}(L)
\end{array}\right]\left[\begin{array}{l}
\ln O F D I_{t} \\
\ln E X M_{t} \\
\ln I M M_{t}
\end{array}\right]+\left[\begin{array}{l}
\varepsilon_{1 t} \\
\varepsilon_{2 t} \\
\varepsilon_{3 t}
\end{array}\right],
$$

OFDI and Services Trade

$$
\left[\begin{array}{l}
\ln O F D I_{t} \\
\ln E X S_{t} \\
\ln I M S_{t}
\end{array}\right]=\left[\begin{array}{l}
b_{1} \\
b_{2} \\
b_{3}
\end{array}\right]+\left[\begin{array}{l}
\Phi_{11}(L) \Phi_{12}(L) \Phi_{13}(L) \\
\Phi_{21}(L) \Phi_{22}(L) \Phi_{23}(L) \\
\Phi_{31}(L) \Phi_{32}(L) \Phi_{33}(L)
\end{array}\right]\left[\begin{array}{l}
\ln O F D I_{t} \\
\ln E X S_{t} \\
\ln I M S_{t}
\end{array}\right]+\left[\begin{array}{l}
e_{1 t} \\
e_{2 t} \\
e_{3 t}
\end{array}\right],
$$

where $E X M_{t}, I M M_{t}, E X S_{t}$ and $I M S_{t}$ denote merchandise exports, merchandise imports, services exports and services imports at time $t$, respectively. $\varepsilon_{t}$ and $e_{t}$ are the residu-

${ }^{13}$ The Department of Statistics, Singapore, published its annual report, which is known as Singapore Investment Abroad. Only annual OFDI data are published in the annual report. The OFDI data correspond with the data downloaded from UNCTAD. 
als with a mean of zero and constant variance. $L$ is the lag operator. The multivariate Granger causality test assesses the null hypothesis of $\theta_{12}(L)$, which is jointly equal to zero. If the null hypothesis is rejected, it is implied that $E X M_{t}$ Granger causes $O F D I_{t}$, given $I M M_{t}$. The restrictions can be tested by employing the standard Wald test, which follows a $\chi^{2}$ distribution. If the variables of interest are non-stationary, then the implications drawn from the usual Wald test statistics are invalid (Sim et al. 1990). Specifically, as pointed out by Toda and Phillips (1993), the Wald test in an integrated unrestricted VAR has nonstandard limit distributions, hence it is important to pre-test the unit root hypothesis for all variables before the Granger causality test is performed.

As our data spans almost three decades, the series may have structural breaks. Perron (1989) showed that the power to reject a unit root decreases when a structural break is ignored. To allow a structural break, Zivot and Andrew's (1992, hereafter ZA) endogenous structural break test is applied. This is a sequential test that uses the full sample and employs a different dummy variable for each possible break date. The advantage of this test is to allow the break date to be endogenously determined within the model. The break date is selected where the $t$-statistic from the ADF test of the unit root is at a minimum (most negative) value.

ZA propose three models to test for a unit root:

(1) Test A, which permits a structural break and takes the form of a shift in the mean, can be written as follows:

$$
\begin{aligned}
\Delta Y_{t} & =\mu+\alpha Y_{t-1}+\theta_{1} D U(\lambda)+\delta t+e_{1 t}, \\
D U(\lambda) & =1, t>T \lambda, \\
& =0, \text { otherwise, }
\end{aligned}
$$

where $D U$ is a dummy variable, $\lambda$ is an integer that takes a value between 0.15 and 0.85 $T$ is the full sample size.

(2) Test B, where the structural break takes the form of a shift in the trend, is represented by

$$
\begin{aligned}
\Delta Y_{t} & =\mu+\alpha Y_{t-1}+\theta_{1} D T(\lambda)+\delta t+e_{2 t}, \\
D T(\lambda) & =t-T \lambda, t>T \lambda, \\
& =0, \text { otherwise, }
\end{aligned}
$$

where $D T$ is the corresponding trend shift variable.

(3) Test C, in which the structural break takes the form of a shift in the mean and the trend, is specified as

$$
\Delta Y_{t}=\mu+\alpha Y_{t-1}+\theta_{1} D U(\lambda)+\theta_{2} D T(\lambda)+\delta t+e_{3 t}
$$

The null hypothesis in all the three models is $\alpha=0$, which implies that the series $Y_{t}$ contains a unit root, while the alternative hypothesis, i.e. $\alpha<0$, implies that the series is a trend-stationary process with a one-time break occurring at an unknown point in time. 


\section{Empirical results}

Table 7 reports the results of the ZA tests. The results suggest that we do not reject the null of a unit root for all the series at the 5 percent level of significance, indicating that all of the time series are non-stationary $I(1)$ in level terms ${ }^{14}$.

Table 7. Zivot-Andrew Results

\begin{tabular}{|c|c|c|c|}
\hline Series & $5 \%$ critical value & \multicolumn{2}{|c|}{ ZA test statistics } \\
\hline \multirow{3}{*}{$\ln O F D I$} & Test A & -3.77 & -4.80 \\
\hline & Test B & -2.81 & -4.42 \\
\hline & Test C & -2.51 & -5.08 \\
\hline \multirow{3}{*}{$\ln E X M$} & Test A & -3.60 & -4.80 \\
\hline & Test B & -3.56 & -4.42 \\
\hline & Test C & -3.54 & -5.08 \\
\hline \multirow{3}{*}{$\ln I M M$} & Test A & -3.64 & -4.80 \\
\hline & Test B & -3.70 & -4.42 \\
\hline & Test $\mathrm{C}$ & -3.72 & -5.08 \\
\hline \multirow{3}{*}{$\ln E X S$} & Test A & -4.47 & -4.80 \\
\hline & Test B & -4.40 & -4.42 \\
\hline & Test C & -4.70 & -5.08 \\
\hline \multirow{3}{*}{$\ln I M S$} & Test A & -2.43 & -4.80 \\
\hline & Test B & -2.30 & -4.42 \\
\hline & Test C & -2.27 & -5.08 \\
\hline
\end{tabular}

Note: The ZA tests are based on Zivot and Andrew's (1992) critical values.

As previously mentioned, the Granger causality tests require that all series be stationary. We converted all of the series into first differences and performed stationarity tests, such as Augmented Dickey Fuller (ADF) and Phillips Perron (PP) tests ${ }^{15}$. If these variables are written in first differences, then both tests suggest that all series are $I(0)$.

Given that all of the variables of interest are $I(1)$, these variables are expressed in first differences in equations (1) and (2) before the causality tests are performed. As the Granger causality test is very sensitive to the number of lags included in the regression, we adopted a set of statistical selection information criteria using the Likelihood Ratio (LR), Final Prediction Error (FPE), Akaike Information Criterion (AIC), Schwarz Criterion (SC) and Hannan-Quinn Information Criterion (HQ) to determine the optimal lag length. Table 8 provides the calculated values of the loss functions based on the

\footnotetext{
${ }^{14}$ We note that one can infer Granger causality if the non-stationary variables are co-integrated. However, there are no theories to justify that there exists a long-run relationship among OFDI, merchandise exports and imports and services exports and imports.

${ }^{15}$ Neither the ADF and PP tests reject the null hypothesis of a unit root for all variables in the levels (see Table 8) and are consistent with the ZA test results reported in Table 7.
} 
proposed information criteria. All of the information criteria choose a lag of 1 as the optimal lag for the tri-variate VAR using the merchandise trade data (see the first panel of Table 9). The same lag-length selection results also apply to the tri-variate VAR using the services trade data, with the exception of $\mathrm{SC}$, which favors lag 0 . Hence, the tri-variate VAR in first differences with 1 lag is estimated for equations (1) and (2).

Table 10 presents the causality test results. There is strong evidence of a unidirectional causality that runs from $\triangle \mathrm{n} F D I$ to $\triangle \ln E X M$, suggesting that Singapore's OFDI Granger causes the growth rate of the merchandise exports. This shows that cross-border direct investments by both locally controlled and foreign-controlled firms have the ability to enhance the country's international competitiveness of export trade and, consequently, encourage merchandise exports. The positive sign of the estimated coefficient confirms the complementary effect of $\triangle \ln O F D I$ on $\triangle \ln E X M$. This finding is consistent with the view that OFDI tends to open an important channel for firms based in Singapore to engage in cross-border intra-firm trade via value-adding activities that could lead to greater efficiency in conducting business within firms to promote merchandise exports. However, there is no evidence supporting the reverse causality from home merchandise exports to Singapore's OFDI.

Table 8. Unit root test results

\begin{tabular}{llcccc}
\hline Series & Type of test & \multicolumn{2}{c}{ ADF } & PP \\
\hline & & In Levels & In first differences & In levels & In first differences \\
\hline $\ln O F D I$ & Intercept & -1.7103 & $-10.5780^{* * *}$ & -1.6053 & $-11.7181^{* * *}$ \\
\hline $\ln E X M$ & Trend \& intercept & -3.1363 & $-4.8270^{* * *}$ & -3.1456 & $-4.7080^{* * *}$ \\
\hline $\ln E X S$ & Trend \& intercept & -1.7495 & $-3.1188^{* *}$ & -2.0005 & $-3.3515^{* *}$ \\
\hline $\ln I M M$ & Trend \& intercept & -2.0949 & $-4.9375^{* * *}$ & -2.1229 & $-4.8327^{* * *}$ \\
\hline $\ln I M S$ & Trend \& intercept & -2.1797 & $-4.1364 * * *$ & -2.1979 & $-4.0574^{* * *}$ \\
\hline
\end{tabular}

Note: $*$ denotes significant at $10 \%, * *$ denotes significant at $5 \%$, *** denotes significant at $1 \%$.

Table 9. Lag length selection

\begin{tabular}{|c|c|c|c|c|c|c|}
\hline Lag & $\log L$ & LR & FPE & AIC & $\mathrm{SC}$ & HQ \\
\hline \multicolumn{7}{|c|}{ Tri-variate VAR(1): $\triangle \ln O F D I, \triangle \ln E X M$ and $\triangle \ln I M M$} \\
\hline 0 & 15.6148 & NA & $7.61 \mathrm{e}-05$ & -0.9703 & -0.8252 & -0.9285 \\
\hline 1 & 29.7713 & $23.9571 *$ & $5.15 \mathrm{e}-05^{*}$ & $-1.3670 *$ & $-0.7863^{*}$ & $-1.1998^{*}$ \\
\hline 2 & 36.0813 & 9.2222 & $6.55 \mathrm{e}-05$ & -1.1601 & -0.1439 & -0.8674 \\
\hline 3 & 42.6261 & 8.0551 & $8.61 \mathrm{e}-05$ & -0.9712 & 0.4804 & -0.5532 \\
\hline \multicolumn{7}{|c|}{ Tri-variate VAR (1): $\triangle \ln O F D I, \Delta \ln E X S$ and $\triangle \ln I M S$} \\
\hline 0 & 51.7095 & NA & $1.14 \mathrm{e}-05$ & -2.8652 & $-2.7305^{*}$ & -2.8193 \\
\hline 1 & 66.6663 & $26.3943 *$ & $8.08 \mathrm{e}-06^{*}$ & $-3.2156^{*}$ & -2.6769 & $-3.0319^{*}$ \\
\hline 2 & 73.9969 & 11.6246 & $9.05 \mathrm{e}-06$ & -3.1174 & -2.1747 & -2.7959 \\
\hline 3 & 81.7283 & 10.9150 & $1.01 \mathrm{e}-05$ & -3.0428 & -1.6960 & -2.5835 \\
\hline
\end{tabular}

Note: * indicates the order of lag length selected by the information criteria. 
Table 10. Causality tests for OFDI, exports and imports

\begin{tabular}{|c|c|c|}
\hline \multicolumn{3}{|c|}{ Tri-variate $\operatorname{VAR}(1): \triangle \ln O F D I, \triangle \ln E X M$ and $\triangle \ln I M M$} \\
\hline Null hypothesis & $\chi^{2}$ (p-value) & Complementary $(+) /$ Substitutionary $(-)$ \\
\hline$\Delta \ln E X M=/=>\Delta \ln O F D I$ & $0.253(0.6143)$ & $(+)^{\#}$ \\
\hline$\Delta \ln O F D I=/=>\Delta \ln E X M$ & $2.969(0.0849) *$ & $(+)$ \\
\hline$\Delta \ln I M M=/=>\Delta \ln O F D I$ & $0.055(0.8131)$ & $(+)$ \\
\hline$\Delta \ln O F D I=/=>\Delta \ln I M M$ & $4.692(0.0303)^{* *}$ & $(+)$ \\
\hline$\Delta \ln I M M=/=>\Delta \ln E X M$ & $3.8695(0.0492)^{* *}$ & $(+)$ \\
\hline$\Delta \ln E X M=/=>\Delta \ln I M M$ & $5.167(0.0230)^{* *}$ & $(+)$ \\
\hline \multicolumn{3}{|c|}{ Tri-variate VAR (1): $\triangle \ln O F D I, \Delta \ln E X S$ and $\Delta \ln I M S$} \\
\hline Null hypothesis & $\chi^{2}$ (p-value) & Complementary / Substitutionary \\
\hline$\Delta \ln E X S=/=>\Delta \ln O F D I$ & $0.068(0.7934)$ & $(-)$ \\
\hline$\Delta \ln O F D I=/=>\Delta \ln E X S$ & $0.004(0.9495)$ & $(+)$ \\
\hline$\Delta \ln I M S=/=>\Delta \ln O F D I$ & $1.269(0.2599)$ & $(+)$ \\
\hline$\Delta \ln O F D I=/=>\Delta \ln I M S$ & $0.009(0.929)$ & $(+)$ \\
\hline$\Delta \ln I M S=/=>\Delta \ln E X S$ & $0.011(0.9156)$ & $(+)$ \\
\hline$\Delta \ln E X S=/=>\Delta \ln I M S$ & $1.348(0.2455)$ & $(+)$ \\
\hline
\end{tabular}

Note: $\Delta$ denotes first differences; \# the sign of the estimated VAR coefficient; *significant at $10 \%$ level, ${ }^{* *}$ significant at $5 \%$ level.

The tri-variate Granger causality test results also suggest the existence of a unidirectional causality from Singapore's OFDI to the growth rate of the merchandise imports. The positive sign of the estimated coefficient implies the complementary effect of the former on the latter. Such evidence would be consistent with backward vertical integration, which involves importing intermediate outputs from the host economies where foreign affiliates undertake their production activities to add value in the home country by their parent firms. This finding is also consistent with Singapore's regionalization drive, which is a long-term strategy to encourage and offer incentives to Singaporean firms to invest abroad so the firms can exploit the lower costs of production in the host economies, especially in Asia, while retaining the more human capital- and technologyintensive stages of production in the home country (see Yeung 2001 and Ellingsen et al. 2006).

Furthermore, the causality test results also indicate a bi-directional causality between the growth rate of merchandise exports and that of merchandise imports. The causation that runs from merchandise exports to merchandise imports suggests that merchandise exports have a high import content, which supports the notion of entrepôt trade and multinational trade and investment activity, both of which involve backward and forward linkages. The reverse causation that runs from merchandise imports to merchandise exports suggests a supply-side view that merchandise imports, especially those used as 
inputs for export production, have the propensity to encourage merchandise exports. The evidence of bi-direction causality between these two variables further supports the sustainability of trade balances, as noted by Tang (2003).

Nonetheless, Table 9 shows that there is no evidence of any causal linkages between Singapore's OFDI and services trade ${ }^{16}$ (exports and imports); OFDI is not able to draw on the services trade because trade in services is not capable of encouraging OFDI. The plausible explanations for this set of Granger causality test results are as follows:

a. The foreign subsidiaries of Singapore-based firms tend to outsource their support services either from the host countries or from their own services-support subsidiaries that have been relocated abroad ${ }^{17}$ as the nature of services is mainly to provide market presence in the consuming country. Hence, there is no evidence of causation that runs from Singapore's OFDI to services exports.

b. The multinationals from Singapore are similarly not involved in the import of intermediate services from abroad for adding value in the home country because their value chain activities in services might not fit into the core activities of their parent companies (e.g., research and development, IT services, product design, marketing, delivery, and provision of after-sale services). Instead, Singapore is highly dependent on foreign expertise to make it a regional and international hub for business, financial and knowledge-based services. Therefore, Singapore continues to attract foreign investments into its business and financial services rather than encouraging OFDI, which explains why the Granger causality test results do not show any evidence of interactions between OFDI and import trade in services.

\section{Conclusions}

Singapore is a city-state economy with limited land and virtually no natural resources. Despite its strategic location in the region, the availability of a skilled workforce and a sophisticated infrastructure, the Singaporean government is encouraging domestic firms to invest in the region in view of rising labor costs, small domestic market size and declining export markets. Cross-border direct investment has become a long-term

\footnotetext{
${ }^{16}$ Causality is based on the notion that the past values of $Y$ can be used to predict $\mathrm{X}$ one period ahead. However, there is a concern about the indirect effects that might exist in multivariate causality tests (e.g. Lütkepohl 1993, 2005; Dufour, Renault 1998; Dufour, Taamouti 2010). For instance, given the presence of an auxiliary variable $\mathrm{Z}$, it is possible that the variable $\mathrm{Y}$ does not cause variable $X$ at horizon one but does cause variable $X$ at a longer horizon via Z. Lütkepohl (1991: 45) states that, "For a stationary $\operatorname{VAR}(p)$, if the first $\mathrm{pK}-\mathrm{p}$ responses of variable $\mathrm{j}$ to an impulse in variable $\mathrm{k}$ are zero, all the following responses must also be zero". As Kónya (2004: 79) stated, "However, if there is no causality between two variables for two periods ahead then there is no causality between them at, or up to longer horizons either". Therefore, we estimated both the tri-variate models with lags 1 and 2 (see Table 10) and found that the results are the same for both lag lengths (i.e. lags 1 and 2), suggesting that the indirect effect is not a concern in this study. We thank the referee for highlighting the indirect causality effect.

${ }^{17}$ For instance, Table 3 shows that a significant range of services activities from Singapore has been operating overseas, which can also potentially complement the foreign production undertaken by Singaporean multinationals.
} 
strategy for Singapore not only to sustain international competitiveness but also to lead the country towards high-technology industrialization. Determining the causal linkages between OFDI from Singapore and Singapore's external trade components (i.e. both exports and imports of merchandise and services) can provide an economic assessment of the ability of the internationalization of firms based in Singapore to forge trade linkages with the export and import sectors with regard to merchandise and services in the era of globalization.

The findings suggest that cross-border direct investments by Singapore-based locally controlled and foreign-controlled firms are instrumental in promoting merchandise trade, particularly exports, thus supporting the OFDI-led trade hypothesis. For instance, the causality test results suggest that Singapore's OFDI activities tend to enhance the international competitiveness of the city-state's merchandise exports by means of intrafirm trade activities and home sourcing, which potentially opens an important channel to boost merchandise export trade. As a result, the regionalization drive initiated by the city-state government is not only able to take advantage of the regional growing business opportunities but also foster a trade relationship with Singapore's merchandise exports. Moreover, the production activities of Singapore's foreign subsidiaries could also establish backward vertical integration that encourages merchandise imports that add value in the home country and thereby complement the home country's exports. However, the present study does not show any evidence of causal interaction between Singapore's OFDI and services trade (i.e. exports and imports) because the Singaporean multinationals often outsource their services either from the host country services sector, where ongoing contact with the former is important (such as accounting, banking, finance and related services), or from their own services-supporting subsidiaries that have been relocated abroad. The city-state is well-known for its strategic location as an operational headquarters, international procurement center and regional distribution center. Therefore, the linkages between Singapore's OFDI and home services sector can be strengthened to promote cross-border direct investment and services trade. To facilitate the relationships between OFDI services and trade, the city-state government could create a platform with incentives that encourage domestic support services that can complement the global operations undertaken by the Singaporean multinationals.

\section{Acknowledgement}

The authors thank Tham Siew Yean (Universiti Kebangsaan Malaysia) for her helpful comments that served to improve the earlier draft. We also thank Jae Kim (University of La Trobe, Australia) for his helpful advice on indirect causality effect. The authors also like to acknowledge research grants from Universiti Sains Malaysia, 304/ PDASAR/6310074 \& 1001/CDASAR/816209. 


\section{References}

Aggarwal, R.; Agmon, T. 1990. The international success of developing country firms: role of government-directed comparative advantage, Management International Review 30: 163-180.

Amiti, M.; Greenaway, D.; Wakelin, K. 2000. Foreign Direct Investment and Trade: Substitutes or Complements? [online], [cited 11 March 2011]. Available from Internet: www.cepr.org/meets/ wkcn/2/2290/papers/amiti.pdf

Bayoumi, T.; Lipworth, G. 1997. Japanese foreign direct investments and regional trade, IMF Working Paper No. WP/97/103. Washington DC: IMF.

Blomqvist, H. 2001. State and development policy: the case of Singapore, Asian Profile 29: 239-253.

Blonigen, B. 2001. In search of substitution between foreign production and exports, Journal of International Economics 53: 81-104. http://dx.doi.org/10.1016/S0022-1996(00)00066-0

Brainard, S. L. 1993. A simple theory of multinational corporations and trade with a trade-off between proximity and concentration, NBER Working Paper No. 4269. Cambridge, Massachusetts: National Bureau of Economic Research.

Brainard, S. L. 1997. An empirical assessment of the proximity connection trade-off between multinationals sales and trade, American Economic Review 87: 520-544.

Chia, S. Y. 1986. Direct foreign investment and the industrialization process in Singapore, in C. Y. Lim, P. Lloyds (Eds.). Resources and Growth in Singapore. Singapore: Oxford University Press, 79-118.

Clausing, K. 2000. Does multinational activity displace trade?, Economic Inquiry 38: 190-205.

Dufour, J. M.; Renault, E. 1998. Short run and long run causality in time series: theory, Econometrica 66: 1099-1125. http://dx.doi.org/10.2307/2999631

Dufour, J. M.; Taamouti, A. 2010. Short and long run causality measures: theory and inference, Journal of Econometrics 154: 42-58. http://dx.doi.org/10.1016/j.jeconom.2009.06.008

Ellingsen, G.; Likumahuwa, W.; Nunnenkamp, P. 2006. Outward FDI by Singapore: a different animal?, Transnational Corporation 12: 1-40.

Fontagné, L. 1999. Foreign direct investment and international trade: complements or substitutes?, OECD Science, Technology and Industry Working Paper 1999/3. Paris: OECD Publishing. Ginevičius, G.; Tvaronavičiene, M. 2005. Inward and outward FDI in Lithuania and Estonia: review of patterns in neighboring countries, Journal of Business Economics and Management 6(4): 179-188.

Goh, S. K.; Wong, K. N. 2011. Malaysia's outward FDI: the effects of market size and government policy, Journal of Policy Modeling 33: 497-510. http://dx.doi.org/10.1016/j.jpolmod.2010.12.008

Goldberg, L. S.; Klein, M. 1999. International trade and factor mobility: an empirical investigation, NBER Working Paper No. 7196. Cambridge, Massachusetts: National Bureau of Economic Research.

Granger, C. W. J. 1969. Investigating causal relations by econometric models and crossspectral methods, Econometrica 37: 424-438. http://dx.doi.org/10.2307/1912791

Granger, C. W. J. 1988. Some recent developments in a concept of causality, Journal of Econometrics 39: 199-211.

Grossman, G. M.; Helpman, E. 1989. Product development and international trade, Journal of Political Economy 97: 1261-1283. http://dx.doi.org/10.1086/261653

Head, K.; Ries, J. 2001. Overseas investment and firm exports, Review of International Economics 9: 108-122. http://dx.doi.org/10.1111/1467-9396.00267 
Helpman, E. 1984. A simple theory of trade with multinational corporations, Journal of Political Economy 92: 451-471. http://dx.doi.org/10.1086/261236

Helpman, E.; Krugman, P. 1985. Market Structure and Foreign Trade. The MIT Press: Cambridge.

Horst, T. 1972. The industrial composition of U.S. exports and subsidiary sales to the Canadian market, American Economic Review 62: 37-45.

Huff, W. 1995. The development state, Singapore, and Singapore's economic development since 1960, World Development 23: 1421-1438. http://dx.doi.org/10.1016/0305-750X(95)00043-C

Islam, I.; Chowdhury, A. 1997. Asia-Pacific Economies: a Survey. London: Routledge.

Kokko, A. 2006. The home country effects of FDI in developed economies, Working Paper No. 225 [online], [cited 11 March 2011]. Available from Internet: www.ideas.repec.org/p/hhs/ eijswp/0225.html

Kónya, L. 2004. Unit-Root, cointegration and Granger causality test results for export and growth in OECD countries, International Journal of Applied Econometrics and Quantitative Studies 1-2: $67-94$.

Kosekahyaoglu, L. 2006. A comparative analysis of FDI in Turkey and CEECS: is there any link between FDI and trade?, Journal of Business Economics and Management 7(4): 193-200.

Lecraw, D. J. 1985. Some evidence on transfer pricing by multinational corporations, in A. M. Rugman, L. Eden (Eds.). Multinationals and Transfer Pricing. New York: St. Martin's Press, 223-246.

Lim, S. H.; Moon, H C. 2001. Effects of outward foreign direct investment on home country exports, Multinational Business Review 9: 42-49.

Lin, A. L. 1995. Trade effects of foreign direct investment: evidence for Taiwan with four ASEAN countries, Weltwirtschaftliches Archiv 131: 737-747. http://dx.doi.org/10.1007/BF02707939

Lipsey, R. E.; Weiss, M. Y. 1984. Foreign production and exports of individual firms, Review of Economics and Statistics 66: 304-308. http://dx.doi.org/10.2307/1925832

Lütkepohl, H. 1991. Introduction to Multiple Time Series Analysis. Berlin: Springer-Verlag. http://dx.doi.org/10.1007/978-3-642-61695-2

Lütkepohl, H. 1993. Introduction to Multiple Time Series Analysis. $2^{\text {nd }}$ ed. Berlin-Heidelberg: Springer-Verlag. http://dx.doi.org/10.1007/978-3-642-61695-2

Lütkepohl, H. 2005. New introduction to Multiple Time Series Analysis. Berlin: Springer-Verlag. Ma, Y.; Morikawa, K.; Shone, R. 2000. A macroeconomic model of direct investment in foreign affiliates of Japanese firms, Japan and the World Economy 12: 953-973.

http://dx.doi.org/10.1016/S0922-1425(00)00045-1

Markusen, J. R. 1984. Multinationals, multi-plant economics, and the gains from trade, Journal of International Economics 16: 205-226. http://dx.doi.org/10.1016/S0022-1996(84)80001-X

Markusen, J. R.; Venables, A. J. 1995. Multinational firms and the new trade theory, NBER Working Paper no. 5036. Cambridge.

Murray, G.; Pereira, A. 1995. Singapore: The Global City-State. London: Heinemann.

Okposin, S. B. 1999. The Extent of Singapore's Investments Abroad. Brookfield: Ashgate.

Pang, E. F. 1987. Foreign investment and the state in Singapore, in V. Cable, B. Persaud (Eds.). Developing with Foreign Investment. London: Croom Helm, 84-100.

Perron, P. P. 1989. The great crash, the oil price shock and the unit root hypothesis, Econometrica 57: 1361-1401. http://dx.doi.org/10.2307/1913712

Pfaffermayr, M. 1996. Foreign outward direct investment and exports in Austrian manufacturing: substitutes or complements?, Weltwirtschaftliches Archiv 132: 501-552.

http://dx.doi.org/10.1007/BF02707510 
Rajan, R. S.; Thangavelu, S. M. 2009. Singapore: Trade, Investment and Economic Performance. World Scientific Press.

Regnier, P. 1991. Singapore: City state in Southeast Asia. London: Hurst \& Company.

Rodan, G. 1989. The Political Economy of Singapore's Industrialization. London: Macmillan.

Sim, C.; Stock, J.; Watson, M. 1990. Inference in linear times series models with unit roots, Econometrica 58: 113-144. http://dx.doi.org/10.2307/2938337

Singapore Department of Statistics. 2008. Singapore's Investment Abroad [online], [cited 31 May 2011]. Available from Internet: http://www.kbrisingapura.com/singapore_highlight/20080711996. pdf

Svensson, R. 1996. Effects of overseas production on home country exports: evidence based on Swedish multinationals, Weltwirtschaftliches Archiv 132: 304-329.

http://dx.doi.org/10.1007/BF02707809

Tang, T. C. 2003. Are imports and exports of the five ASEAN economies co-integrated? An empirical study, International Journal of Management 20: 88-91.

Toda, H. Y.; Phillips, P. C. B. 1993. Vector autoregressions and causality, Econometrica 61: 1367-1393. http://dx.doi.org/10.2307/2951647

UNCTAD. 2005. Case Study on Outward Foreign Direct Investment by Singaporean Firms: Enterprise Competitiveness and Development. New York and Geneva: United Nations.

UNCTAD. 2008. World Investment Report 2009. New York and Geneva: United Nations.

UNCTAD. 2009. World Investment Report 2009. New York and Geneva: United Nations.

Wong, K. N.; Tang, T. C.; Fausten, D. K. 2009. FDI and services trade: evidence from Malaysia and Singapore, Global Economic Review 38: 265-276. http://dx.doi.org/10.1080/12265080903157318

Yeung, H. W. 1999. Singapore's Global Reach: an Executive Report. Singapore: National University of Singapore.

Yeung, H. W. 2001. Organising regional production networks in Southeast Asia: implications for production fragmentation, trade, and rules of origin, Journal of Economic Geography 1: 299-321. http://dx.doi.org/10.1093/jeg/1.3.299

Zivot, E.; Andrews, D. W. K. 1992. Further evidence on the great crash, the oil-price shock, and the unit-root hypothesis, Journal of Business and Economic Statistics 10(3): 251-270.

Koi Nyen WONG is an Associate Professor in the Business School, Sunway University, Malaysia. His research areas are FDI, trade and development economics. His recent work has been published in Applied Economics, The World Economy, Journal of Policy Modeling, Journal of Economic Studies, International Economic Journal, Global Economic Review and Tourism Economics.

Soo Khoon GOH is Currently Attached to the Centre for Policy Research and International Studies at Universiti Sains Malaysia (Science University of Malaysia), Penang, Malaysia. She received her PhD in economics from the University of Melbourne, Australia. Her main research interests lie in macroeconomics and international economics. Her latest publication with Koi Nyen Wong on "Malaysia's outward FDI: The effects of Market Size and Government Policy" can be found in the Journal of Policy Modeling 33(3), May 2011. 